Skills for Creative Industries graduate success

Ruth Bridgstock*

Queensland University of Technology, Australia

*ARC Centre for Excellence in Creative Industries and Innovation, Queensland University of Technology, Australia. Email: r.bridgstock@qut.edu.au 


\section{Skills for Creative Industries graduate success}

Purpose - Although there is increasing evidence that the creative industries are essential to national economic growth as well as social and cultural well-being, creative graduates often find it difficult to become established professionally. This study investigates the value of career management competence and intrinsic career motivations (as elements of 'protean career orientation') in predicting positive graduate outcomes.

Design/methodology - Self-report surveys were administered to 208 creative industries graduates from two Australian universities at two points in time: at course completion, and one year later.

Findings - Individual career management competence and intrinsic work motivations, measured at course completion, were significant predictors of early career success, using both subjective and objective measures, measured one year later.

Practical implications - This study suggests that an emphasis on student development beyond the traditional 'key' employability skills may well be worthwhile. The article also suggests a broad learning and teaching approach by which universities can encourage the development of student career identity, and thus engender student intrinsic career motivations and career self management skills and behaviours.

Originality/value - This is one of the first studies to demonstrate empirically a link between a particular set of skills and graduate outcomes. In addition, it provides insights into the role of student career motivations in positive transitions to the world of work in the creative industries.

Keywords: creative industries, graduate skills, employability, higher education, intrinsic motivation, education to work transition

Paper type: research paper 


\section{Introduction}

The literature is replete with discussions of the generic and discipline-specific skills and knowledge university graduates may require in order to be employable. Somewhat less attention has been given to the influence of motivational and attitudinal characteristics on graduate employability (Tomlinson, 2007) and remarkably little has been said about the importance of career management skills, which are the cluster of abilities required to navigate the world of work. Career management skills are those involved in obtaining suitable employment and further educational opportunities, and intentionally building a career (Bridgstock, 2009). In sectors such as the creative industries, where the labour force is fluid and graduate entry is highly competitive (Ball, 2003; Harvey and Blackwell, 1999) it makes sense that tenacious graduates with strong internal drive and well-developed career management competencies (in addition to outstanding job skills) will experience better outcomes. This article evaluates the impact of career management competence and work motivations on the early career outcomes of two cohorts of graduates from creative industries degree courses in Australia.

\subsection{The creative industries}

The 'creative industries' have been the subject of much discussion in academic, policy and industry circles since the sector's inception only a decade ago. The creative industries encompass "those activities which have their origin in individual creativity, skill and talent and which have the potential for wealth and job creation through the generation and exploitation of intellectual property” (Department for Culture Media and Sport, 1998, 3). As such, the creative industries include long-established 'cultural' industries such as crafts, music, dance, publishing, and the creative arts, as well as relative newcomers emphasising digital content such as software and multimedia design.

The justification for grouping such an eclectic mix of industries together is largely economic. It is now widely accepted that advanced nations are shifting to information-based, knowledgedriven 'creative economies', where creativity is a key determinant of economic growth (Department for Culture Media and Sport, 2008, Department of Communications Industry Technology and the Arts, 2008). The creative industries are seen as being instrumental to success in this context (Florida, 2003; Howkins, 2002). Indeed, in Australia and the United Kingdom both creative industries employment rates and creative industries' contributions to GDP are 
growing at more than twice their national averages (Higgs et al., 2008, 2007). As well as contributing to the economy directly, the creative industries are also significant drivers of economic growth across other industries (Potts, 2007). The mechanism by which the creative industries do this is similar to that operating through the science, technology and education sectors (Edquist, 1997): they originate and synthesise innovation in the underlying knowledge base of the economy (Hearn and Rooney, 2008; National Endowment for Science Technology and the Arts, 2006).

\subsection{Working in the creative industries}

The creative industries labour force exhibits a profile which is quite distinctive. In contrast with more conventional industries such as financial services or manufacturing, the sector is dominated by networked clusters of small-to-medium enterprises, , sole-traders and micro-businesses (Creigh-Tyte and Thomas, 2001). Work in the creative industries is often freelance or performed on a short-term contractual basis, as creative businesses constantly form and re-form valuechains to create new products.

Creative industries careers are characterised by 'boundarylessness’ (Arthur and Rousseau, 1996), in that they are largely individually navigated, often with minimal opportunity for stable employment or hierarchical progression within a firm (Bridgstock, 2005; Cunningham \& Higgs, 2010). In addition, although the average levels of education of creative workers is similar to professionals from other sectors (Florida, 2003; Throsby and Hollister, 2003), decisions regarding employment in the sector are much less likely to rely on formal educational credentials or professional accreditation than in other sectors, but rather are often dependent on informal contacts and the quality of previous work outputs.

There have been fewer studies of the early labour market experiences of graduate creative workers than of professional creatives, but there is fairly strong evidence that many emerging creatives find it very difficult to establish themselves (Ball et al., 2010). Because demand for graduate level jobs in certain occupations often exceeds supply, and obtaining whatever shortterm positions are available is often reliant on 'who you know', many graduates experience an extended education-to-work transition period including multiple entry attempts (Ball, 2003; Blackwell and Harvey, 1999). In order to build a portfolio of work and create much-needed career networks, emerging creatives may undertake further specialist training or unpaid 
internships (Blackwell and Harvey, 1999). They may experience spells of unemployment and underemployment during this entry phase. Multiple job-holding within and outside the creative sector, and reliance on family for financial support, is common amongst graduate creatives (Galloway et al., 2002).

Research using Census and Labour Force Survey data suggests that while some creatives find destinations in core creative industries sub-sectors, an equal number eventually become 'embedded' in creative occupations outside the creative industries (Higgs et al., 2008, 2007). A further proportion will fail to 'break in' to the creative industries entirely and may eventually pursue careers in other sectors and occupations. Creative Industries advocates suggest that by virtue of their training, creative graduates maintain skills, practices and other attributes which make them valuable throughout the innovation economy, such as interpersonal skills, the capacity to manage uncertainty and ambiguity, and certain types of inductive problem solving ability (ARC Centre of Excellence for Creative Industries and Innovation, 2007). However, many new graduates may not be aware of, and/or are reluctant to consider, options outside their core specialisms.

\subsection{Preparing students for work in the creative industries}

Over the last ten years, the idea of graduate employability has been the subject of much interest by universities, as league tables have received increasing scrutiny and moves have been made towards making public funding contingent upon performance in key areas including research, teaching quality, and graduate outcomes (Department of Education Science and Training, 2007; Higher Education Funding Council for England, 2002). Graduate employability is commonly defined as the ability to obtain and maintain work at a graduate level, and in both the United Kingdom and Australia the performance indicator used is full-time graduate-level employment, measured by questionnaire a few months after course completion (Graduate Careers Australia, 2008; Higher Education Statistics Agency, 2007). As previously discussed, the entry level labour market into which Creative Industries graduates emerge is highly competitive, the concept of 'graduate level work' is not as relevant as in other sectors, and full-time employment opportunities are unusual. It is unsurprising that creative industries courses report consistently lower graduate employability results than courses within other fields. 
Further, national level reviews have suggested continuing mismatches between the skills and abilities of Creative Industries graduates, and those required in the workforce. The Higher Education Funding Council for England's national study of employability in higher education (Higher Education Funding Council for England, 2003) reported significant differences between the skills graduates indicated they had developed while at university, and those that managers believed were requirements for employment. The United Kingdom's Lambert Review of Business-University Collaboration (2003) likewise found that Creative Industries employers were concerned that with the recent proliferation of Creative Industries-related courses, that many were not properly equipping students with the skills they needed for successful careers in the sector.

To date, the chief mechanism by which universities have engaged with the graduate employability agenda is via development of generic 'key' skills such as communication, numeracy, literacy, and problem solving, along with certain desirable personal qualities. These attributes are either embedded in the curriculum or developed through stand-alone courses (Bowden et al., 2000; Fallows, 2000). The argument is that these skills and qualities will make graduates appealing to a range of employers by virtue of their transferability; that they will promote work-readiness; and also enhance work performance.

The idea of promoting and developing performance enhancing skills which can then be transferred to a multiplicity of employment roles and scenarios is certainly appealing, and the key skills approach is very popular throughout the higher and vocational education sectors in the United Kingdom and Australia. However, a number of strong criticisms have been levelled at key skills as a graduate employability enhancement strategy. Pervasive definitional and measurement issues aside (Canning, 2007; Leveson, 2000), there is evidence of underlying conceptual problems. For instance, researchers have encountered difficulties in showing that skills and knowledge learned in 'decontextualised' classrooms can be transferred to workplace situations, or from once workplace context to another (Hyland and Johnson, 1998), indicating that perhaps generic key skills have more 'specificities' associated with them than initially thought. In addition, empiricists have so far been unable to demonstrate empirically any enhancement of graduate employment outcomes arising from key skills programmes (Cranmer, 2006; Mason et al., 2003). 
At the level of graduate employment and beyond, well-developed discipline specific skills and knowledge are just as, if not more, important than key skills in determining employability. Professional-level discipline-specific content continues to be the core element in university provision, which means that universities must address the challenge of skills mismatches and gaps employers complain of in emerging creating workers (Higher Education Funding Council for England, 2003). However much effort creative industries programme providers go to in order to match current or projected skill needs, it seems inevitable that some degree of mismatch will remain (Boswell et al., 2004; Gordon, 1986). Rapid change in workforce requirements (particularly in digital skills and knowledge) means that skill forecasting will always be inaccurate. In addition, given the fluidity of the creative industries labour market, it is impossible to identify the exact destinations of graduates ahead of time, and thus know what their various skill needs are going to be. Finally, the process of renovating course content can be unwieldy, time-consuming, and expensive, and by the time the process is completed, courses are often once again out of date.

Although it is desirable to undertake periodic course updating and also to create new courses as sub-disciplines emerge, pursuing a perfect skills match is probably not the best approach to enhance Creative Industries graduate employability. Rather than attempting the impossible task of meeting all of the requirements associated with the myriad work possibilities the creative graduate may encounter, it is more realistic for universities to focus on stable, enduring domainspecific knowledge and skills (in addition to key skills embedded into curricula), and for fastturnaround informal, vocational or workplace-based training to provide necessary targeted development opportunities for emergent specialist skills. What may be just as valuable for universities, in the pursuit of creative graduate employability, is to assist students to develop the propensity and abilities necessary to take personal responsibility for their own career development in an ongoing way, including the responsive acquisition and deployment of necessary work skills. As early as the 1970s, Hall (1976) described workers who exemplify these kinds of characteristics and practices protean careerists.

\subsection{The creative worker as 'protean careerist'}

Hall's choice of the term 'protean career' drew upon Greek mythology, and the story of the god Proteus who could change his shape at will. The conceptualisation of the protean career is also grounded in Shepard's (1984) notion of career as a "path with heart” and pursuing personal 
meaning in career (Hall and Mirvis, 1996). Hall described the protean career as a career orientation in which the individual, rather than the organisation, is in charge, where the person's core values drive career decisions, and where the main success criteria are subjective (Hall, 2004). Thus, the two central elements of the protean career are self-directed career behaviour, and intrinsic motivations for career (Briscoe and Hall, 2006).

This concept of protean career orientation becomes of particular interest to the present discussion in the light of what is known about creative workers' boundaryless career patterns. In contrast to a 'traditional', 'hierarchical' career, a boundaryless career is not bounded by a single organisation or field, and is marked by non-linearity, and less stability. In this career pattern, the onus is on the worker to recurringly obtain or create employment and manage their career progression (Arthur et al., 1999). As previously discussed, evidence from labour force studies and economic modelling suggests that many creative workers are engaged in boundaryless career (Bridgstock, 2005). In the boundaryless career, much greater imperatives exist for individuals to manage their own careers (Arnold and Jackson, 1997). Informed by protean career theory, the present study explores the predictive value of career self-management skills and intrinsic work motivations to successful tertiary graduate transitions to the world of work in the creative industries.

\section{Method}

The present study uses a prospective, quantitative approach to investigate the value of work motivations and career self-management skills to the early career outcomes of creative industries graduates. This approach was chosen because: (1) it permits generalisability of findings to the wider population of creative industries graduates; (2) it eliminates common method bias, which occurs when predictor and outcome variables are measured at once, and (3) it does not rely on participants' recollections of their skill or career outcome levels at a previous time, which can be inaccurate.

\subsection{Participants}

The sample comprised graduating students from 3-year undergraduate creative industries courses at two large metropolitan Australian universities who were tracked forward one year from the point of course completion as they moved into the world of work. At time one, 311 creative 
industries graduands were asked about their perceived levels of career management competence, work values, courses studied, and socio demographic information.

At time two, one year after they had completed their courses, the creative industries graduates were contacted by email, phone and letter, and invited to participate in a second online survey. A total of 253 graduates responded, representing an 81.35\% response rate. Of these, 208 had attempted to enter the creative industries workforce during the previous year (the majority of the remainder having decided to undertake further study); panel data from these 208 graduates was analysed in this study. At time two, the participants indicated how much they were earning from creative industries employment, how much they were earning overall, and assigned themselves a self-defined career success rating. Thus, it was possible to build a prospective model to examine the predictive value of measured variables at the point of course completion to a successful one year education-to-work transition.

\subsection{Predictor variables}

Career Management Competence. Two subscales of the Career Management Competence (CMC) scale (Bridgstock, 2009) based on the Australian Blueprint for Career Development (Haines et al., 2003) were included in the questionnaires at time one. The Blueprint comprises 11 competencies and associated key performance indicators, within a four stage learning taxonomy. The subscales used in this study were: (i) self management, comprising six 1-6 Likert scale items (from 'not at all confident' to 'very confident') relating to internally focussed career skills such as building and maintaining a positive self image; changing and growing throughout life; participating in lifelong learning; and maintaining balanced life and work roles, and (ii) career building, comprising five items relating to externally focussed career skills such as finding and obtaining work, locating and using career information, and making career enhancing decisions. The CMC scale items and their corresponding dimensions are presented in Appendix A. Work Motivations. At time one, participants gave their own definitions of career success in response to an open-ended question. These definitions were content analysed to determine the participants' dominant work motivations. The definitions were successfully categorised by two coders into two groupings (with acceptable Cohen's kappa level of .80 or greater). The two categories were: intrinsic work motivations, including definitions relating to work being performed for inherent satisfactions (e.g., self-determination, skill development, enjoyment, and 
interest); and extrinsic work motivations, including definitions relating to work being performed for separable outcomes (including external evaluation, status, and recognition from others) (Ryan and Deci, 2000).

\subsection{Background variables}

A number of background variables were incorporated into the models, as they were potential sources of bias to the results. Creative industries course discipline was dummy coded into two variables, based on the three course discipline categories included in the study. The dummy variables were: creative arts courses; and performing arts courses. The remaining category was technical and digital arts/design courses. The course disciplines in the study are categorised in Table 1.

Table 1. Creative industries course categories by discipline

\begin{tabular}{lll}
\hline Creative Arts & Performing Arts & Technical \& Digital Arts / Design \\
\hline Visual Arts & Acting & Technical Production \\
Creative Writing & Dance & Communication Design \\
& Drama / Performance Studies & Film and Television \\
Music & Sound Design \\
& & Games Design \\
& & Multimedia Design \\
& & Fashion Design \\
\hline
\end{tabular}

In addition, participant gender and University were dummy coded for inclusion in the models, with female and University 2 as the reference categories. Participant age in years was also included in the models, as a continuous predictor variable.

\subsection{Outcome variables}

Three outcome variables were measured at time two to indicate successful education to work transition in the group studied. First, total annual income was chosen as an 'objective' measure of career success. Because many emerging creative workers engage in multiple job-holding both within and outside the creative sector, creative industries annual income was chosen as a second outcome variable. The third outcome variable was subjective career success rating, based on the participants' responses to a 1-6 Likert scale question asked at time two: “How successful have you been in your career so far?”, ranging from 'not at all', to 'very'. Thus, both subjective and objective dimensions of career success (Heslin, 2005) were included in the study. 
Analyses

In order to determine the predictive value of career management competence and work motivations to the creatives' career success one year after graduation, the predictor and background variables were entered in to three regression models. Standard Ordinary Least Squares regression modelling procedures were used for the two income (total and creative industries) models, to permit the calculation of the unique contribution of each predictor variable, outside of the influence of all of the other predictor variables.

For the subjective career success rating model, an ordered probit approach was used. An ordered probit model is appropriate when the outcome variable is ordinal, as ordinary linear regression models make the assumption that the differences between categories of the outcome variable are equal, which is not necessarily the case when a Likert scale is used (Daykin \& Moffatt, 2002). Prior to constructing the regression models, descriptive and diagnostic statistical procedures were undertaken to ensure that relevant statistical assumptions were met.

\section{Results}

Descriptive results for all of the variables of interest are presented in Table 2. Just over half (58.65\%) of the participants were from university 1, and four in ten (37.98\%) were male. Slightly fewer than one-third (31.25\%) had completed creative arts courses, 35.10\% had completed performing arts courses, and the remainder (37.98\%) were technical / design graduates. At time one, three quarters (75.96\%) gave responses which were coded as 'solely or primarily intrinsic motivations' (with 21.63\% giving responses which contained elements of both intrinsic and extrinsic work motivations). At time two, one year later, the average age of the graduates was 23 years. Their median total yearly income was \$26,000 AUD, of which \$15,000 AUD was creative industries-related. The mean 1-6 career success rating was 3.55, almost exactly at the mid 'neutral' point of the career scale. 
Table 2. Descriptive statistics for variables included in the regression models, $\mathrm{N}=208$

\begin{tabular}{|c|c|c|c|c|c|}
\hline & $\%$ & Mean & $S D$ & Minimum value & Maximum value \\
\hline \multicolumn{6}{|l|}{ Predictor Variables } \\
\hline $\begin{array}{l}\text { Career management competence } \\
\text { - self management }\end{array}$ & & 28.32 & 4.40 & 12.00 & 36.00 \\
\hline $\begin{array}{l}\text { Career management competence } \\
\text { - career building }\end{array}$ & & 20.94 & 4.33 & 10.00 & 30.00 \\
\hline $\begin{array}{l}\text { Work motivations - dummy } \\
\text { coded intrinsic }\end{array}$ & $75.96 \%$ & & & & \\
\hline \multicolumn{6}{|l|}{ Background variables } \\
\hline $\begin{array}{l}\text { University - dummy coded } \\
\text { university } 1\end{array}$ & $58.65 \%$ & & & & \\
\hline $\begin{array}{l}\text { Creative industries discipline - } \\
\text { dummy coded creative arts }\end{array}$ & $31.25 \%$ & & & & \\
\hline $\begin{array}{l}\text { Creative industries discipline - } \\
\text { dummy coded performing arts }\end{array}$ & $35.10 \%$ & & & & \\
\hline Gender - dummy coded male & $37.98 \%$ & & & & \\
\hline Age & & 23.08 & 4.54 & 19.00 & 39.00 \\
\hline \multicolumn{6}{|l|}{ Outcome variables } \\
\hline Total annual income (AUD) & & 26,701 & 11,636 & 6,000 & 84,000 \\
\hline $\begin{array}{l}\text { Creative industries income } \\
\text { (AUD) }\end{array}$ & & 17,769 & 11,727 & 2,000 & 84,000 \\
\hline Subjective career success rating & & 3.55 & 1.45 & 1.00 & 6.00 \\
\hline
\end{tabular}

Table 3. Bivariate correlations between variables included in the regression models, $\mathrm{N}=208$

$\begin{array}{llllllllll}1 . & 2 . & 3 . & 4 . & 5 . & 6 . & 7 . & 8 . & 9 . & 10 .\end{array}$

\section{Predictor Variables}

1. Career management competence - self management

2. Career management competence - career building

3. Work motivations - dummy $\quad .29 * * \quad .24 * * \quad 1.00$ coded intrinsic

\section{Background variables}

4. University - dummy coded university 1

$\begin{array}{lllllll}5 . & \text { Creative industries discipline }- & .03 & .04 & .02 & .06 & 1.00\end{array}$ dummy coded creative arts

$\begin{array}{lllllll}\text { 6. Creative industries discipline }- & .00 & -.04 & .08 & .02 & -.50^{* *} & 1.00\end{array}$ dummy coded performing arts

$\begin{array}{llllllll}\text { 7. Gender - dummy coded male } & -.06 & .03 & -.09 & -.01 & -.19 * * & .05 & 1.00\end{array}$

8. Age

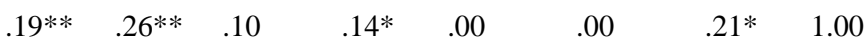

\section{Outcome variables}

9. Total annual income (log)

10. Creative industries income

(log)

$\begin{array}{lllllllllllll}\text { 11. Subjective career success } & .33^{* *} & .33^{* *} & .32^{* *} & .02 & .09 & -.26^{* *} & -.06 & .18^{* *} & .42^{* *} & .59^{* *} & 1.00\end{array}$
rating

$$
\text { * significant at } \mathrm{p}<.05 * * \text { significant at } \mathrm{p}<.01
$$


In preparation for regression modelling, the income variables were logarithmically transformed to correct for skewness. Bivariate correlations were calculated, as shown in Table 3. The correlation between the two CMC scales was quite high ( $\mathrm{r}=.57)$, indicating a potential problem with multicollinearity. However, none of the tolerance values were lower than .65, and collinearity diagnostics did not reveal a problem; therefore, both $C M C$ variables were included in the models.

\subsection{Model results for total income (log)}

The first regression model results for the prediction of graduate total income (log) are presented in Table 4. The total variance accounted for by the model was .31; this was significantly different from zero, at $\mathrm{p}<.01(\mathrm{~F}(8,199)=12.74)$. The most important predictor of total income (log) was creative industries discipline, with creative arts and performing arts disciplines both found to be predictive of lower total incomes than technical / design disciplines $\left(\mathrm{sr}_{\mathrm{i}}{ }^{2}=-.27\right.$ and -.35 respectively; $\mathrm{p}<.01$ for both). Both of the CMC subscales also contributed significantly to the prediction of total income (log), although career building was a stronger predictor than self management $\left(\mathrm{sr}_{\mathrm{i}}^{2}=.21, \mathrm{p}<.01\right.$ and $\left.\mathrm{sr}_{\mathrm{i}}^{2}=.12, \mathrm{p}<.05\right)$.

None of the other variables contributed significantly to the prediction of total income (log). The bivariate correlation between age and total income (log) was positive and significant at $\mathrm{p}<.01$, but age was not a significant predictor in the model (although it approached significance). Age was also noted to be positively correlated with the CMC scales (at $\mathrm{p}<.01$ ), suggesting that the relationship between age and total income is mediated by the relationship between career management competence and income (Barron and Kenny, 1986) - simply put, that age may lead to increased career management competence, which in turn predicts higher income levels. 
Table 4. OLS regression model statistics for total income (log)

\begin{tabular}{lllll}
\hline B & S.E. & $\beta$ & $\mathrm{sr}_{\mathrm{i}}^{2}$ & $\mathrm{t}$ \\
\hline 9.03 & .20 & & & $44.23^{* *}$ \\
.01 & .00 & .14 & .12 & $2.01^{*}$ \\
& & & & \\
.03 & .00 & .26 & .21 & $3.66^{* *}$ \\
.10 & .06 & .09 & .08 & 1.56 \\
& & & & \\
.00 & .05 & .00 & .00 & .04 \\
& & & & \\
-.30 & .07 & -.32 & -.27 & $-4.73^{* *}$ \\
-.38 & .06 & -.41 & -.35 & $-6.18^{* *}$ \\
& & & & \\
.04 & .06 & .04 & .04 & .68 \\
.01 & .00 & .10 & .10 & 1.62 \\
\hline
\end{tabular}

Constant

Career management

competence - self

management

Career management

competence - career building

Work motivations - dummy

coded intrinsic

University - dummy coded university 1

Creative industries discipline

- dummy coded creative arts

Creative industries discipline

- dummy coded performing

arts

Gender -dummy coded male

Age

Model statistics

R $\quad .58$

$\mathrm{R}^{2}$ (adj)

$\mathrm{F}(8,199)$

$12.74^{* *}$

* significant at $\mathrm{p}<.05 * *$ significant at $\mathrm{p}<.01$

\subsection{Model results for creative industries income (log)}

The second regression model results for the prediction of graduate creative industries income (log) are presented in Table 5. The total variance accounted for by the model was .36, which was statistically significant at $\mathrm{p}<.01(\mathrm{~F}(8,199)=15.58)$. As with the model for total income, performing and creative arts disciplines predicted lower creative industries incomes $\mathrm{sr}_{\mathrm{i}}{ }^{2}=-.21$ and -.42 respectively; $\mathrm{p}<.01$ for both). Non-parametric post hoc tests revealed significant disciplinary differences in creative industries income at time two $\left(\chi^{2}(2)=26.75, \mathrm{p}<.01\right)$, with creative arts, performing arts, and technical/design graduates earning median creative industries incomes of $\$ 16,000, \$ 12,000$ and $\$ 20,000$ respectively in the year subsequent to course completion. 
Once again, the CMC subscales contributed significantly to the model, and career building was a stronger predictor of creative industries income than self management $\left(\mathrm{sr}_{\mathrm{i}}^{2}=.25, \mathrm{p}<.01\right.$ and $\mathrm{sr}_{\mathrm{i}}{ }^{2}=$ $.21, \mathrm{p}<.05)$. Age continued to be non-significant in the model, yet was significantly correlated with both the CMC scales and creative industries income, suggesting a mediation relationship. By contrast with the model for total income, in the present model, intrinsic work motivation was also a significant positive predictor, at $\mathrm{p}<.05\left(\mathrm{sr}_{\mathrm{i}}^{2}=.13\right)$. It was also positively correlated with both CMC scales, at $\mathrm{p}<.01$. Post hoc tests showed that intrinsically motivated graduates had significantly higher scores on the CMC scales $(t(206)=3.59$ for self management and $t(206)=4.30$ for career building, $\mathrm{p}<.01$ ).

Table 5. OLS regression model statistics for creative industries income (log)

\begin{tabular}{llllll} 
& $\mathrm{B}$ & $\mathrm{S} . \mathrm{E}$. & $\beta$ & $\mathrm{sr}_{\mathrm{i}}{ }^{2}$ & $\mathrm{t}$ \\
\cline { 2 - 6 } Constant & 7.70 & .30 & & & $26.02^{* *}$ \\
$\begin{array}{l}\text { Career management competence }- \\
\text { self management }\end{array}$ & .02 & .01 & .15 & .12 & $2.14^{*}$ \\
$\begin{array}{l}\text { Career management competence - } \\
\text { career building }\end{array}$ & .05 & .01 & .31 & .25 & $4.43^{* *}$ \\
$\begin{array}{l}\text { Work motivations - dummy } \\
\text { coded intrinsic }\end{array}$ & .21 & .09 & .14 & .13 & $2.30^{*}$ \\
$\begin{array}{l}\text { University - dummy coded } \\
\text { university 1 }\end{array}$ & .06 & .08 & .04 & .04 & .79 \\
$\begin{array}{l}\text { Creative industries discipline - } \\
\text { dummy coded creative arts }\end{array}$ & -.28 & .09 & -.20 & -.21 & $-3.06^{* *}$ \\
$\begin{array}{l}\text { Creative industries discipline }- \\
\text { dummy coded performing arts }\end{array}$ & -.59 & .09 & -.42 & -.42 & $-6.53^{* *}$ \\
Gender -dummy coded male & .07 & .08 & .05 & .05 & .86 \\
Age & .02 & .01 & .10 & .09 & 1.69 \\
\hline Model statistics & & & & & \\
\hline $\mathrm{R}$ & .62 & & & & \\
$\mathrm{R}^{2}$ (adj) & .36 & & & & \\
$\mathrm{~F}$ (8,199) & $15.58 * *$ & & & & \\
\hline
\end{tabular}

* significant at $\mathrm{p}<.05 * *$ significant at $\mathrm{p}<.01$

3.3 Model results for subjective career success rating 
The third regression model used an ordered probit approach to investigate predictors of the graduates' subjective career success ratings at one year after course completion. The final model which maximised the log likelihood of the outcomes observed in the data was a significant improvement over the initial 'intercept only’ model, with a -2 Log Likelihood value of 457.80 , $\chi^{2}(3)=22.09, \mathrm{p}<.01$. The important predictors in this model included self management (coefficient .05, Wald 5.40, $\mathrm{p}<.01$ ); intrinsic work motivations (coefficient .76, Wald 17.08, $\mathrm{p}<.01$ ), and creative industries discipline, with performing arts discipline predicting lower career success ratings (coefficient -.84, Wald 21.62, $\mathrm{p}<.01$ ). Unlike the regression models for income, career building was not a significant predictor in the model. However, career building and age were both shown earlier to be positively correlated with subjective career success ratings, as well as with self management scores, and each other. These findings point to the presence of a complex mediating relationship between age, self management competence and career building competence in predicting subjective career success in creative industries graduates.

Table 5. Ordered probit model statistics for subjective career success rating

\begin{tabular}{|c|c|c|c|}
\hline & \\
\hline & Estimate & S.E. & Wald \\
\hline $\begin{array}{l}\text { Career management } \\
\text { competence - self } \\
\text { management }\end{array}$ & .05 & .02 & $5.40 * *$ \\
\hline $\begin{array}{l}\text { Career management } \\
\text { competence - career building }\end{array}$ & .04 & .02 & 3.03 \\
\hline $\begin{array}{l}\text { Work motivations - dummy } \\
\text { coded intrinsic }\end{array}$ & .76 & .18 & $17.08 * *$ \\
\hline $\begin{array}{l}\text { University - dummy coded } \\
\text { university } 1\end{array}$ & .10 & .15 & .47 \\
\hline $\begin{array}{l}\text { Creative industries discipline } \\
\text { - dummy coded creative arts }\end{array}$ & -.28 & .18 & 2.37 \\
\hline $\begin{array}{l}\text { Creative industries discipline } \\
\text { - dummy coded performing } \\
\text { arts }\end{array}$ & -.84 & .18 & $21.62 * *$ \\
\hline Gender - dummy coded male & -.06 & .16 & .17 \\
\hline Age & .02 & .02 & 1.08 \\
\hline \multicolumn{4}{|l|}{ Model statistics } \\
\hline $\begin{array}{l}\text { Intercept only -2 Log } \\
\text { Likelihood }\end{array}$ & 720.19 & & \\
\hline Final -2 Log Likelihood & 652.98 & & \\
\hline$\chi^{2}(8)$ & $67.21 * *$ & & \\
\hline
\end{tabular}




\section{Discussion}

Although a link between student career self management and graduate work outcomes is intuitively appealing and reflects a position that has been espoused by several authors in the career development field (Bridgstock, 2009; Mayston, 2002; Watts, 2006), the present study is the first to demonstrate empirically that a group of final year undergraduate students who report having well-developed career self management skills experience higher levels of subjective and objective career success after graduation. Further, intrinsic motivations for work were able to be linked both with career management skills and career success (particularly subjective success). As such, this study provides support for the notion that creative graduates who exemplify Hall's (Briscoe and Hall, 2006; Hall, 1976, 2004) notion of the protean careerist as being intrinsically motivated in career and engaging in self-directed career behaviour, experience better initial career outcomes than those who do not.

Two background variables were also of particular note in the present results. First, perhaps unsurprisingly, participant age was positively related to possession of career management skills and also to the various measures of career success, although older graduates were not more likely than younger graduates to report intrinsic career motivations. The findings with respect to statistical mediation would appear to suggest that one of the reasons that the older graduates had better outcomes than younger graduates was that they tended to possess better developed career management skills. One might propose that that the reason older graduates reported stronger career management skills than younger graduates is simply that they were likely to have had more experience in navigating the world of work.

Second, strong disciplinary differences were found for graduate outcomes, with performing and creative arts graduates earning significantly less than digital/technical graduates, and performing arts graduates also reporting significantly lower subjective career success ratings than creative and digital/technical graduates. These disciplinary differences did not extend to career selfmanagement skills or career motivations. The disciplinary differences in income levels were congruent with what has been reported elsewhere (Bridgstock, 2005; Higgs, 2008; Throsby and Hollister, 2003).

\subsection{Building career management competence at university}

The present findings suggest that a protean career orientation has a positive effect on the graduate outcomes of creative industries students. If universities are to become serious about the 
graduate employability agenda in creative fields, one approach is to engender protean career orientations in their students; that is, to encourage intrinsic career motivations, and the development of skills for (and a propensity towards) career self management.

Extant literature shows that career identity (Meijers, 1998) may be an issue for many young emerging creatives (Stokes et al., 2003). The OECD’s (2002) Review of Career Guidance Policies commented that "many students in tertiary education appear to have little idea of why they are there or where it is leading” (18). Students can enter creative courses with only the vaguest of notions regarding what they will do afterwards, influenced by unrealistic or romantic ideas about the world of work in their fields, or with an overly rigid, foreclosed and unrealistic career identity (e.g., having a career just like that of film director Peter Jackson). These career identity issues influence their engagement with learning during the course, and also their careerrelated behaviours afterwards. A key task to be undertaken in the first half of creative industries courses is to support students through an iterative process of adaptive career identity building, whereby students reflect upon their own core career needs and values, and in turn learn about, and experience first-hand where possible, various aspects of their intended occupations.

This iterative and reflective process of career identity building emphasises the 'self management' aspects of career management skills. During this process, students are encouraged to consider questions such as: 'what drew me to this course? What are my core work values, and how can the range of career options open to me fit with those values? What skills will I require in my intended career, and how will I acquire those? What combination of subsidised and commercial work am I aiming for? Will I need to move to another place to find the work I want? How will I cope with setbacks? How do I want work to fit in with the rest of my life?' This process may involve 'turning students on' to career opportunities they had not yet considered, or helping them to refine their ideas about work and careers. It will also involve encouraging students to continue this reflective process for themselves in an ongoing way, and suggesting strategies for doing so. University careers services can play an important role in student career identity building. All UK and Australian universities maintain their own careers services, which offer career guidance and support to students. However, the resourcing of these services seems to vary considerably (Organisation for Economic Cooperation and Development, 2002), and the emphasis can be on course choice rather than career management competence and facilitation of graduates’ 
transitions to work (Watts, 2005). If appropriately resourced, careers service staff can contribute to curriculum development by providing expertise in the theory and practice of career planning.

The career identity building process as just described should commence in the first year of a university degree. Once this process is well underway, students will be better positioned to find personal relevance and therefore engage actively with learning opportunities offered during the course, and also to drive their own discipline-specific and generic skill acquisition, in line with their own goals. They will also be more likely to connect with the outward 'career building' aspects of career management skill acquisition as they are offered. Thus, the second half of undergraduate creative industries courses should be involved with the development of industryspecific knowledge and know-how, including how to build industry networks, and how to find and obtain or create work (including portfolio creation).

The development and implementation of the two phases of student career management programs will obviously involve investment in partnerships between creative industries faculties and industry. Both the career identity (self-management) and career building phases will ideally involve extensive industry involvement, both in the classroom (via such mechanisms as master classes, mentoring and project work), and through authentic, situated learning opportunities such as industry-based internships (Crebert et al., 2004). Students, “... learn best by being able to experiment with ideas, by 'doing' and networking with others, and by working with more experienced mentors in their sector" (Raffo et al., 2000, 356). Effective career self-management is based on a foundation of knowledge of the world of work, along with self-knowledge. For maximal graduate employability via career self-management, students should be permitted the opportunity to 'try on' various work roles, and also to practice career navigation during the relative safety of their time as undergraduates.

\section{Conclusion}

The present research provides empirically-based support for the contention that abilities beyond the 'employability skills' usually targeted through university curricula can have graduate employability effects. While generic and discipline-specific skills should remain central to creative industries undergraduate courses, further thought should be given to the concurrent development of career management skills - those skills involved in intentional career building. Career management course provision should involve much more than is currently provided by 'capstone' courses during the final year. It should be embedded throughout the curriculum. 
This study depended on data from self-report questionnaires of graduates at two points in time. Although the findings are persuasive, they should be corroborated using other cohorts and other methods. Subsequent research should clarify the nature of the relationship between career management skills and career motivations, and could also explore links between career management skills, the development of discipline-specific and generic skills, and graduate employability. These questions lend themselves to large scale, longitudinal quantitative research with multiple data collection episodes during and beyond university, employing both 'objective' assessments and self-report measures of skill development.

Significant further research is also needed to identify ways that career management skills can best be developed through the university experience. Of particular interest is the development of student career identity, and how this agenda might be pursued in first year, concomitant with the development of university student identity and necessary academic skills. There may be some utility in incorporating a significant degree of inquiry-based learning in the first year of study ('the upside-down curriculum' - see, for instance, Lindgren, 2010) as a vehicle for student reflective practice and career identity development. Appropriate scaffolding from academic advisors, careers education specialists, industry mentors and possibly more advanced students or recent graduates, is important to the success of such an endeavour. An initial step could be to trial these suggestions with a small number of creative disciplines in a university, and to evaluate it using a participatory action research spiral (McTaggart, 1991), gaining qualitative initial feedback from students and other stakeholders. The trial sample should ideally be large enough to pursue a quantitative pre- and post-test approach as well, which would include measures of student capability and career identity. 


\section{REFERENCES}

ARC Centre of Excellence for Creative Industries and Innovation (2007), Educating for the creative workforce: Rethinking arts and education, Report for Australia Council for the Arts (Sydney).

Arnold, J. and Jackson, C. (1997), "The new career: Issues and challenges", British Journal of Guidance \& Counselling, 25, pp.427-433.

Arthur, M., Inkson, D., and Pringle, J. (1999), The new careers: Individual action and economic change, Sage, London.

Arthur, M. \& Rousseau, D. M. (1996), The boundaryless career: A new employment principle for a new organizational era, Oxford University Press, Oxford.

Ball, L. (2003), Future directions in employability research in the creative industries, Report for Learning and Teaching Support Network (Brighton).

Ball, L., Pollard, E. and Stanley, N. (2010), Creative graduates, creative futures, Report for Report for Council for Higher Education in Art and Design (London).

Blackwell, A. and Harvey, L. (1999), Destinations and reflections: Careers of British art, craft and design graduates, Report for Centre for Research into Quality (Birmingham).

Boswell, C., Stiller, S. and Straubhaar, T. (2004), Forecasting labour and skills shortages: How can projections better inform labour migration policies, Report for European Commission, DG Employment and Social Affairs (Hamburg).

Bowden, J., Hart, G., King, B., Trigwell, K. and Watts, O. (2000), Generic capabilities of ATN university graduates. Available online at: http://www.clt.uts.edu.au/ATN.grad.cap.project.index.html (accessed January 5 2008).

Bridgstock, R. (2005), "Australian artists, starving and well-nourished: What can we learn from the prototypical protean career?", Australian Journal of Career Development, 14(3), pp. 40-48.

Bridgstock, R. (2009), "The graduate attributes we've overlooked: Enhancing graduate employability through career management skills", Higher Education Research and Development, 28(1), pp. 27-39.

Briscoe, J. P. and Hall, D. T. (2006), "The interplay of boundaryless and protean careers: Combinations and implications", Journal of Vocational Behavior, 69(1), pp. 4-18.

Canning, R. (2007), "Reconceptualising core skills", Journal of Education and Work, 20(1), pp. 17-26.

Cranmer, S. (2006), "Enhancing graduate employability: Best intentions and mixed outcomes", Studies in Higher Education, 31(2), pp. 169-184.

Crebert, G., Bates, M., Bell, B., Patrick, C., and Cragnolini, V. (2004), "Developing generic skills at university, during work placement and in employment: Graduates' perceptions", Higher Education Research and Development, 23(2), pp. 147-165.

Creigh-Tyte, A. and Thomas, B. (2001), "Employment", in Selwood, S. (Ed.), The UK cultural sector: Profile and policy issues, Policy Studies Institute, London.

Cunningham, S., \& Higgs, P. (2010). What's your other job? A census analysis of arts employment in Australia. Melbourne: Australia Council for the Arts.

Daykin, A. R. and Moffatt, P. G. (2002), "Analyzing ordered responses: A review of the ordered probit model", Understanding Statistics, 1(3), pp. 157-166.

Department for Culture Media and Sport (1998), Creative industries mapping document 1998, Report for Department for Culture, Media and Sport (London). 
Department for Culture Media and Sport (2008), Creative Britain: New talents for the new economy, Report for Department for Culture Media and Sport, (London).

Department of Communications Industry Technology and the Arts (2008), Creative Australia, Report for Australia 2020 Summit (Canberra).

Department of Education Science and Training (2007), Learning and teaching performance fund 2007. Available online at:

http://www.dest.gov.au/sectors/higher_education/policy_issues_reviews/key_issues/learn ing_teaching/ltpf/documents/Learning_Teaching_Perf_Fund_2007_pdf.htm (accessed April 30 2007).

Edquist, C. (1997), Systems of innovation: Technologies, institutions and organizations, Pinter, Washington.

Fallows, S. (2000), "Building employability skills into the higher education curriculum: A university-wide initiative", Education and Training, 42(2), pp. 75-83.

Florida, R. (2003), The rise of the creative class: And how it's transforming work, leisure, community and everyday life, Pluto Press, North Melbourne.

Galloway, S., Lindley, R., Davies, R., and Scheibel, F. (2002), A balancing act: Artists' labour markets and the tax and benefit systems, Report for Arts Council of England.

Gordon, A. (1986), "Education and training for information technology", Studies in Higher Education, 11(2), pp. 189-198.

Graduate Careers Australia (2008), Graduate Destination Survey. Available online at: http://www.graduatecareers.com.au/content/view/full/957 (accessed September 10 2008).

Haines, K., Scott, K., and Lincoln, R. (2003), Australian Blueprint for Career Development: Draft prototype. Available online at: http://www.dest.gov.au/directory/publications/australian_blueprint.pdf (accessed March 20 2007).

Hall, D. (1976), Careers in organizations, Goodyear, Santa Monica.

Hall, D. (2004), "The protean career: A quarter-century journey", Journal of Vocational Behaviour, 65(1), pp. 1-13.

Hall, D. and Mirvis, P. (1996), "The new protean career: Psychological success and the path with a heart", in Hall, D. T. (Ed.), The career is dead - long live the career: A relational approach to careers, Jossey-Bass, San Francisco, pp. 15-45.

Harvey, L. and Blackwell, A. (1999), Destinations and reflections: Careers of British art, craft and design graduates, Report for CRQ (Birmingham).

Hearn, G. and Rooney, D. (Eds.) (2008), Knowledge policy: Challenges for the twenty first century, Edward Elgar, Cheltenham.

Heslin, P. A. (2005), "Conceptualizing and evaluating career success", Journal of Organizational Behavior, 26(2), pp. 113-136.

Higgs, P. (2008), "Overview of employment in the creative segments in 2006", Brisbane, ARC Centre of Excellence in Creative Industries and Innovation.

Higgs, P. L., Cunningham, S. and Bakhshi, H. (2008), Beyond the creative industries: Mapping the creative economy in the United Kingdom, Report for NESTA (London).

Higgs, P. L., Cunningham, S., and Pagan, J. D. (2007), Australia's creative economy: Basic evidence on size, growth, income and employment, Report for Faculty Research Office, ARC Centre of Excellence in Creative Industries and Innovation (Brisbane).

Higher Education Funding Council for England (2002), Performance indicators in higher education in the UK, 1999-2000, 2000-1, Bristol, Higher Education Funding Council for England. 
Higher Education Funding Council for England (2003), How much does higher education enhance the employability of graduates? Available online at:

http://www.hefce.ac.uk/pubs/rdreports/2003/rd13_03/) (accessed 6 October 2010).

Higher Education Statistics Agency (2007), Performance indicators in higher education in the UK 2006/07. Available online at: http://www.hesa.ac.uk/index.php/content/view/1166/141/ (accessed 10 October 2009).

Howkins, J. (2002), The creative economy: How people make money from ideas, Penguin, London.

Hyland, T. and Johnson, S. (1998), "Of cabbages and key skills: Exploding the mythology of core transferable skills in post-school education", Journal of Further and Higher Education, 22(2), pp. 163-172.

Lambert, R. (2003), Lambert review of business-university collaboration. Available online at: http://www.hm-treasury.gov.uk/d/lambert_review_final_450.pdf

Leveson, L. (2000), "Disparities in perceptions of generic skills: Academics and employers", Industry and Higher Education, 14(3), pp. 157-164.

Lindgren, C. (2010). Teaching matters: Turning the teaching of sciences upside down. The Chronicle of Higher Education, April 18 2010. Retrieved from http://chronicle.com/article/Teaching-Matters-Turning-the/65132/

Mason, G., Williams, G., Cranmer, S., and Guile, D. (2003), How much does higher education enhance the employability of graduates?, Report for The Higher Education Funding Council for England (Bristol).

Mayston, D. (2002), Evaluating the benefits of career guidance, Report for Centre for Guidance Studies, University of Derby (Derby, UK).

Meijers, F. (1998), "The development of a career identity", International Journal for the Advancement of Counselling, 20(3), pp. 191-207.

National Endowment for Science Technology and the Arts (2006), Creating growth: How the UK can create world class creative business, Report for NESTA (London).

Organisation for Economic Cooperation and Development (2002), OECD Review of Career Guidance Policies - Australia Country Note. Available online at: http://www.oecd.org/dataoecd/17/47/1948341.pdf (accessed 5 October 2010).

Potts, J. (2007), "Art and innovation: An evolutionary economic view of the creative industries", UNESCO Observatory e-journal, 1(1).

Raffo, C., Lovatt, A., Banks, M., and O'Connor, J. (2000), "Teaching and learning entrepreneurship for micro and small businesses in the cultural industries sector", Education \& Training, 42(6), pp. 356-364.

Ryan, R. M. and Deci, E. L. (2000), "Intrinsic and extrinsic motivations: Classic definitions and new directions", Contemporary Educational Psychology, 25(1), pp. 54-67.

Shepard, H. A. (1984), "On the realization of human potential: A path with heart", in Arthur, M., Bailyn, L., Levinson, D. J., and Shepard, H. A. (Ed), Working with careers, Columbia University, Graduate School of Business, New York, pp. 25-46.

Stokes, H., Wierenga, A., and Wyn, J. (2003), Young visions: Young people's perceptions of career, education, vocational education and training, enterprise education, and part-time work, Report for Enterprise and Career Education Foundation (Canberra).

McTaggart, R. (1991). Principles for participatory action research. Adult Education Quarterly, 41(3), 168-187.

Throsby, C. D. and Hollister, V. (2003), Don't give up your day job: An economic study of professional artists in Australia, Australia Council for the Arts, Sydney. 
Tomlinson, M. (2007), "Graduate employability and student attitudes and orientation to the job market", Journal of Education and Work, 20(4), pp. 285-304.

Watts, A. G. (2005), "Career guidance policy: An international review", Career Development Quarterly, pp. 1-8.

Watts, A. G. (2006), Career development learning and employability. Available online at: http://www.heacademy.ac.uk/learningandemployability.htm (accessed August 10 2006). 
About the author:

Dr Ruth Bridgstock is Vice Chancellor's Research Fellow within the Australian Research Council Centre of Excellence in Creative Industries and Innovation, based at Queensland University of Technology in Australia. Her research interests relate to lifelong individual career and organisational development in the post-compulsory education and business contexts of the 21st century. Her PhD research took a longitudinal approach to the investigation of individual and contextual predictors of graduate employability and early career success in the creative industries. Ruth's current fellowship project 'Creating Innovators' (http://www.creatinginnovators.com) is concerned with building and testing theory relating to effective university education for careers in the innovation sectors, based on the trajectories of high flyers in the fields of science, technology, and the creative industries. 